\title{
Habitat Ecology and Ichthyofaunal Diversity of Two Creeks and Their Associated Streams from Port Blair, South Andaman Islands
}

\author{
M. Arun Kumar, S. Venu, and G. Padmavati \\ Department of Ocean Studies and Marine Biology, Pondicherry University, Brookshabad Campus, P.O. Bag No. 26, \\ Chakkaragaon (Post), Port Blair 744112, India \\ Correspondence should be addressed to M. Arun Kumar; arun4kavi@gmail.com
}

Received 14 September 2015; Revised 24 November 2015; Accepted 5 January 2016

Academic Editor: L. M. Chu

Copyright ( 2016 M. Arun Kumar et al. This is an open access article distributed under the Creative Commons Attribution License, which permits unrestricted use, distribution, and reproduction in any medium, provided the original work is properly cited.

\begin{abstract}
Habitat ecology and ichthyofaunal diversity were analyzed from two creeks and their associated streams in Port Blair: one was perennial and the other one was seasonal. Various habitat types like riffles, pools, and major and minor bends in both streams were studied. The perennial stream has 12 riffles and 14 pools from head point to the entering point of the creek. The seasonal stream has 15 riffles and 13 pools from the starting point to the sink. The perennial stream was found to have higher ichthyofaunal diversity than the seasonal stream: 1701 individuals constituting 8 orders, 30 families, 42 genera, and 54 species were recorded. Among these, 395 specimens represented by 21 species were found in perennial stream, 291 specimens with 11 species were found in seasonal stream, 863 specimens by 48 species were noted in creek, and 152 specimens constituting 14 species in sink were recorded. The physicochemical parameters of the habitats showed more or less a similar trend. The average dissolved oxygen value of the perennial stream was higher than that of the seasonal stream. Higher temperature values were noted during the postmonsoon season. This study has indicated a wide lacuna in the knowledge of the fresh water habitats and their inhabitants on these islands.
\end{abstract}

\section{Introduction}

The Andaman and Nicobar group of islands are located in the Bay of Bengal between $6^{\circ} 45^{\prime}-13^{\circ} 41^{\prime} \mathrm{N}$ and $92^{\circ} 12^{\prime}-93^{\circ} 57^{\prime} \mathrm{E}$ approximately in a North-South direction in the shape of a crescent. These islands have unique ecological systems, mainly contributed by coral reefs, mangroves, seagrass, and seaweed beds [1]. The fish fauna of these islands consist of an assemblage of about 1450 species spread over all the diverse habitats representing 586 genera belonging to 175 families. The fish diversity in Andaman Islands and Nicobar Islands is of special interest in terms of marine zoogeography because of the confluence in the fishes of Andaman Sea with that of the Western Pacific and the Indian Ocean [2]. Apart from marine fishes, many fresh and brackish water species also come under the exploited fishery resources of these islands. The production of fresh water fishes from the inland waters in these islands is 90 tonnes per year. The exploitation and scope for further development are limited due to the lack of major riverine systems [3].

There is so much focus on the diversity of the marine environment around these islands and the fresh water ecology is significantly negligible. But it has to be noted that as much important as the marine environment is the rich rainforest ecosystem in these islands and the numerous water bodies nestled in the depths of the rainforest. Though not having a magnitude with regard to size, it is undisputable that they harbour a great percentage of wildlife yet to be discovered. Due to lack of accurate inventories, information on many of the taxa, in particular the fresh water fishes, is inadequate [4]. Though there were some early contributions on fresh water fish fauna, most of these were patchy or restricted to a particular group. These include studies on diversity [5-8], diversity and distribution $[9,10]$, and a study on Gobiidae [11]. Herre had recorded 112 species of fresh water and littoral fish and his study is the most comprehensive work so far $[9,10]$. 


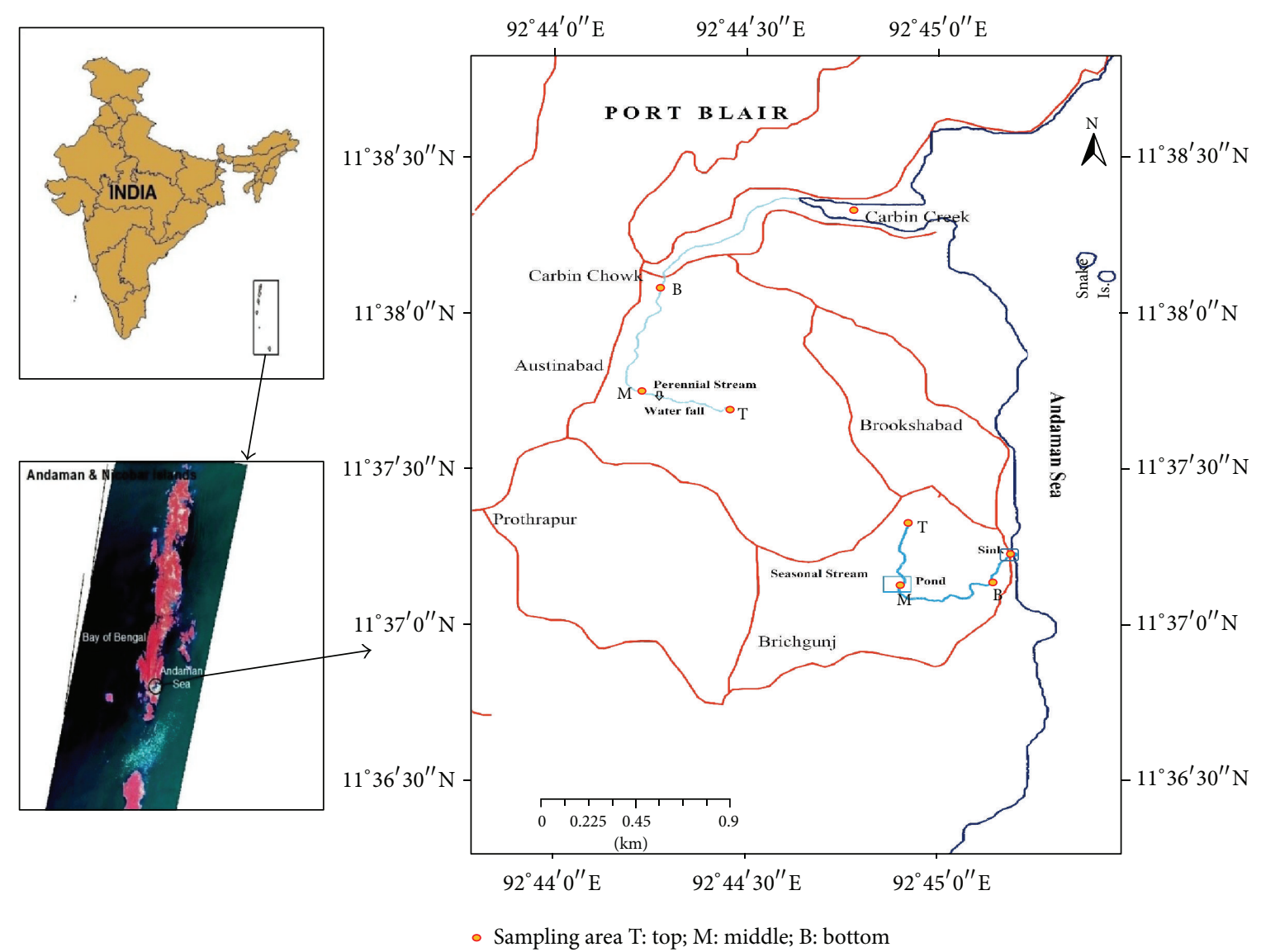

FIGURE 1: Map showing the study area.

Later studies on fresh water fishes of Andaman Islands were merely compilations of previous surveys [12]. Vijay and Priya have done a survey of the fishes in fresh water ecosystems and prepared a checklist [13], comparing it to that of Herre's.

Fish assemblages have widely been used as ecological indicators to assess and evaluate the level of degradation and health of rivers and streams at various spatial scales [14]. In streams, the structural complexity may be understood as a mosaic of mesohabitat patches (such as pools, runs or raceways, and riffles) which are clearly delimited by different combinations of current, depth, and substrate composition [15]. Thus, it is predictable that each mesohabitat holds a peculiar ichthyofauna in response to such habitat features. The current study focusses on the habitat ecology and fish diversity of two creeks in which two different streams empty their water.

\section{Materials and Methods}

2.1. Study Area. The study was conducted season-wise from the month of October 2012 to July 2013. The study area was from Brichgunj to Carbyn's Cove, southeastern side of Port Blair (Figure 1). Two different fresh water streams, one perennial and one seasonal, are flowing from the top of the hill and are emptying themselves into the sea. The study was
TABLE 1: Habitat types of fresh water streams [16].

\begin{tabular}{lccc}
\hline Habitat type & Depth $(\mathrm{m})$ & Current $(\mathrm{m} / \mathrm{sec})$ & Turbulence \\
\hline Pool & Variable & $<0.2$ & No \\
Side pool & $<0.5$ usually & Nil usually & No \\
Plunge pool & $<2.0$ usually & $<0.20$ & Yes \\
Run & Variable & $0.20-0.75+$ & No \\
Riffle & $<0.5$ & $>0.75$ & Yes \\
Cascade & 2.0 usually & $>2.0$ & Much \\
\hline
\end{tabular}

conducted on four major habitats, namely, two streams and two creeks, in which these two streams empty their water. The creek in which the perennial stream emptied was bigger than the other one. The freshwater streams flow to the creeks which have seawater influx.

2.2. Sample Collection and Analysis. The environmental parameters such as dissolved oxygen, $\mathrm{pH}$, salinity, and temperature of these habitats were studied season-wise using standard methods [17]. The habitat types were examined based on a combination of depth, current speed, and turbulence [16] (Table 1). The fishes were collected using cast nets of various sizes $(2,540 \mathrm{~mm} \times 7 \mathrm{~mm}$ and $2,032 \mathrm{~mm} \times 10 \mathrm{~mm})$, drag nets, baited hook, and lines and by hand-picking. The 
species-wise numbers were recorded during each sampling. The length and weight were measured for the collected fishes. The identification was done using standard identification keys [18-21]. Care was taken after obtaining the specimens so as not to kill them. Certain ambiguous fish species were brought to the laboratory for taxonomic identification and confirmation. The rest were released back into the waters immediately after identification. The collected specimens were preserved in formalin and deposited in the fishery museum, Department of Ocean Studies and Marine Biology, Pondicherry University, Port Blair.

2.3. Statistical Analysis. The data were processed and graphs were plotted using the Analytical Package of Microsoft Excel (2013 version). Four different indices were used to assess the diversity of fishes including the following.

2.3.1. Margalef's Diversity Index (D). Margalef's Diversity Index is a measure of the number of species present for a given number of individuals:

$$
D=\frac{(S-1)}{\log N},
$$

where $S$ is total number of species; $N$ is total individuals.

2.3.2. Simpson's Index $\left(D_{s}\right)$. Simpson's Index is considered as dominance index because it weighs the abundance of the most common species:

$$
D_{s}=\sum_{i-1}^{s} \frac{\left(n_{i}\left(n_{i}-1\right)\right)}{(N(N-1))},
$$

where $n_{i}$ is the number of individuals in the $i$ th species. $N$ is total individuals. Since $D_{s}$ and diversity are negatively related, Simpson's Index is usually expressed as the reciprocal $(1-D)$ so that as the index goes up, so does diversity.

2.3.3. Shannon-Weiner Index $\left(H^{\prime}\right)$. The Shannon-Weiner Index is used for measuring diversity. It assumes that all species are represented in a sample and that the sample was obtained randomly:

$$
H^{\prime}=-\sum_{i=1}^{s} p_{i} \ln p_{i},
$$

where $p_{i}$ is the proportion of individuals found in the $i$ th species and $\ln$ is the natural logarithm.

2.3.4. Evenness (E). We can compare the actual diversity value to the maximum possible diversity by using a measure called evenness. The evenness of the sample is obtained from the formula

$$
E=\frac{H^{\prime}}{H_{\max }}=\frac{H^{\prime}}{\ln S} .
$$

The diversity indices were carried out using the software PAST [22].

\section{Results}

3.1. Physicochemical Parameters. The analysis of physicochemical parameters from these habitats showed more or less a similar trend. The $\mathrm{pH}$, salinity, and temperature have shown little variation between the streams from the top to bottom. While dissolved oxygen varied between $3.39 \mathrm{mg} \cdot \mathrm{L}^{-1}$ and $4.34 \mathrm{mg} \cdot \mathrm{L}^{-1}$ in perennial stream (Table 2 ), it was $3.03 \mathrm{mg} \cdot \mathrm{L}^{-1}$ to $4.12 \mathrm{mg} \cdot \mathrm{L}^{-1}$ in seasonal stream (Table 3 ). The higher value for average dissolved oxygen recorded in the perennial stream when compared to the seasonal stream may be attributed to the continuous water flow throughout the year. The salinity and $\mathrm{pH}$ values showed less variation seasonally. High temperature $\left(27-31^{\circ} \mathrm{C}\right)$ and moderate to low dissolved oxygen (3.03$3.89 \mathrm{mg} \cdot \mathrm{L}^{-1}$ ) values were recorded during postmonsoon in both streams (Tables 2 and 3).

The values for physicochemical parameters for the creek and the sink were comparable to each other but entirely different for the two streams. The dissolved oxygen in the creek was found to be between $3.89 \mathrm{mg} \cdot \mathrm{L}^{-1}$ and $4.35 \mathrm{mg} \cdot \mathrm{L}^{-1}$ (Table 4) while in the sink it ranged from $3.62 \mathrm{mg} \cdot \mathrm{L}^{-1}$ to $4.23 \mathrm{mg} \cdot \mathrm{L}^{-1}$ (Table 5). The temperature, salinity, and $\mathrm{pH}$ were more or less similar in both streams when compared to creek and sink (Tables 2-5). Among the four habitats (the two streams, creek, and sink), the values were more or less the same, and the perennial stream had the lowest average $\mathrm{pH}$, temperature, and salinity (Table 2 ). Season-wise values of the physicochemical parameters of all the habitats showed significant variation ( $p>0.05$, one-way ANOVA) among themselves.

3.2. Habitat Types. One stream starts its flow from the head point situated near the top of the hill which is present between Brookshabad and Brichgunj and is flowing northeast. This stream has continuous water flow over the heavy rocky substratum on the hill, with a waterfall near Austinabad, and then it flows over a soft sandy bottom. It mixes with the canal from Austinabad and then with another drainage channel from the airport at Carbyn's Cove. Finally it mixes with the sea through the creek. The seasonal stream does not flow continuously, but the water is present as pools. This stream has a continuous flow only during the rainy season. The water is stored during times of overflow in a pond which is present near the Brichgunj quarry. Finally it mixes with the sea in the eastern side of the hill. There is a small sink near the shore to which the water will be emptied. Only during high tide does it mix with the sea because of the obstruction by a small road.

The results have shown that the major habitat types of both streams were side pools, riffles, pools, runs, cascades, and plunge pools, where their relative numbers play a major role in the faunal distribution. The perennial and seasonal streams both have almost the same number of riffles and pools (Figure 2). The perennial stream has 12 riffles and 14 pools from head point to the entering point of creek. The seasonal stream has 15 riffles and 13 pools from the starting point to the sink. A major difference was that the side pools, plunge pools, runs, and cascades are more in perennial stream than the seasonal stream. There were 7 plunge pools in 
TABLE 2: Physicochemical properties of the water in the perennial stream.

\begin{tabular}{lccccccccc}
\hline Parameters & \multicolumn{3}{c}{ Premonsoon } & \multicolumn{3}{c}{ Monsoon } & \multicolumn{3}{c}{ Postmonsoon } \\
Area & Top & Middle & Bottom & Top & Middle & Bottom & Top & Middle & Bottom \\
\hline Salinity $(\%)$ & 0 & 0 & 27 & 0 & 0 & 24 & 0 & 0 & 30 \\
$\mathrm{pH}$ & 7 & 7 & 7.6 & 7 & 7 & 7.3 & 7 & 7 & 7.9 \\
Temperature $\left({ }^{\circ} \mathrm{C}\right)$ & 25 & 26 & 27 & 24 & 24 & 27 & 26 & 28 & 30 \\
Dissolved oxygen $\left(\mathrm{mg} \cdot \mathrm{L}^{-1}\right)$ & 3.39 & 3.68 & 3.94 & 3.89 & 4.34 & 4.23 & 3.43 & 3.73 & 4.09 \\
\hline
\end{tabular}

TABLE 3: Physicochemical properties of the water in the seasonal stream.

\begin{tabular}{lccccccccc}
\hline Parameters & \multicolumn{3}{c}{ Premonsoon } & \multicolumn{3}{c}{ Monsoon } & \multicolumn{3}{c}{ Postmonsoon } \\
Area & Top & Middle & Bottom & Top & Middle & Bottom & Top & Middle & Bottom \\
\hline Salinity (\%o) & 0 & 0 & 28 & 0 & 0 & 24 & 0 & 0 & 30 \\
$\mathrm{pH}$ & 7 & 7 & 7.5 & 7 & 7 & 7.4 & 7 & 7 & 7.7 \\
Temperature $\left({ }^{\circ} \mathrm{C}\right)$ & 25 & 25 & 26 & 23 & 25 & 26 & 27 & 28 & 31 \\
Dissolved oxygen $\left(\mathrm{mg} \cdot \mathrm{L}^{-1}\right)$ & 3.2 & 3.38 & 3.76 & 3.67 & 4.12 & 4.01 & 3.03 & 3.58 & 3.9 \\
\hline
\end{tabular}

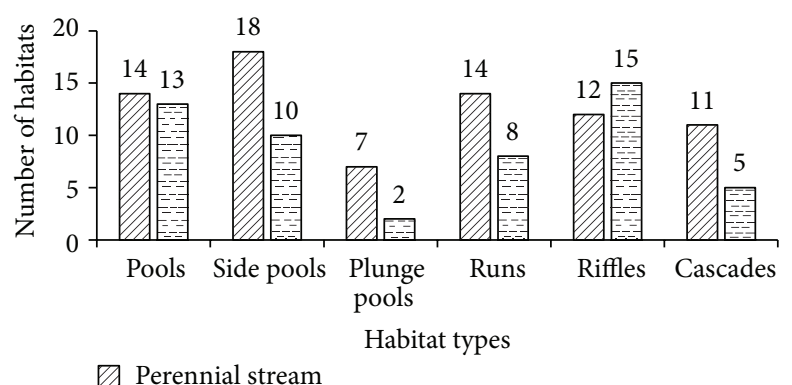

$\square$ Perennial stream

圈 Seasonal stream

FIgURE 2: Habitats in the streams.

TABLE 4: Physicochemical properties of the water in the creek.

\begin{tabular}{lccc}
\hline Parameters & Premonsoon & Monsoon & Postmonsoon \\
\hline Salinity (\%) & 28 & 30 & 34 \\
pH & 7.5 & 7.8 & 8.1 \\
$\begin{array}{l}\text { Temperature } \\
\left({ }^{\circ} \mathrm{C}\right)\end{array}$ & 26 & 30 & 33 \\
$\begin{array}{l}\text { Dissolved } \\
\text { oxygen } \\
\left(\mathrm{mg} \cdot \mathrm{L}^{-1}\right)\end{array}$ & 3.89 & 4.35 & 3.91 \\
\hline
\end{tabular}

TABLE 5: Physicochemical properties of the water in the sink.

\begin{tabular}{lccc}
\hline Parameters & Premonsoon & Monsoon & Postmonsoon \\
\hline Salinity $(\% 0)$ & 29 & 31 & 35 \\
pH & 7.5 & 7.7 & 8.2 \\
Temperature $\left({ }^{\circ} \mathrm{C}\right)$ & 27 & 31 & 33 \\
$\begin{array}{l}\text { Dissolved oxygen } \\
\left(\mathrm{mg} \cdot \mathrm{L}^{-1}\right)\end{array}$ & 3.62 & 4.23 & 3.89 \\
\hline
\end{tabular}

the perennial and 2 plunge pools in the seasonal stream. Totally, 14 runs were found in the perennial stream and 8 runs in the seasonal stream. The perennial stream had 11 cascades and the seasonal stream had 5 cascades. An artificial pond located in the middle of the seasonal stream had a remarkably high diversity of fishes. The two streams were almost similar in terms of habitat parameters but highly varied in their ichthyofaunal assemblages. The creek is located near the bridge to Carbyn's Cove beach and it mixes with the sea. The sink has a vegetation of grasses growing on a deep muddy bottom, containing brackish water which mixes with the sea during high tide.

3.3. Diversity of Fishes in Their Habitats. Species distribution is the manner in which group of species are spread out. The distribution of species over space and time is very useful in understanding the species biodiversity. This study has recorded a total of 1701 individuals constituting 8 orders, 30 families, 42 genera, and 54 species. Among these, 395 individuals represented by 21 species were found in perennial stream, 291 individuals with 11 species were found in seasonal stream, 863 individuals by 48 species were noted in Carbyn's creek, and 152 individuals constituting 14 species were recorded in the sink (Table 6).

Totally, 54 species were identified in all the habitats, with Liza vaigiensis (139), Ambassis interruptus (124), Oreochromis mossambicus (94), Liza parsia (78), and O. niloticus (76) representing maximum individuals. Among these, 8 species were found in all the habitats, A. interruptus, O. mossambicus, 
TABLE 6: Species composition of fishes in the study area.

\begin{tabular}{|c|c|c|c|c|c|}
\hline Taxonomy & Species & Perennial stream & Seasonal stream & Creek & Sink \\
\hline $\begin{array}{l}\text { Order: Anguilliformes } \\
\text { Family: Anguillidae }\end{array}$ & Anguilla sp. & + & + & - & - \\
\hline Family: Muraenidae & Echidna rhodochilus & + & - & + & - \\
\hline $\begin{array}{l}\text { Order: Clupeiformes } \\
\text { Family: Clupeidae }\end{array}$ & Sardinella gibbosa & - & - & + & - \\
\hline \multirow{3}{*}{ Family: Engraulidae } & Stolephorus commersonnii & - & - & + & - \\
\hline & S. indicus & - & - & + & - \\
\hline & Thryssa baelama & - & - & + & - \\
\hline $\begin{array}{l}\text { Order: Aulopiformes } \\
\text { Family: Synodontidae }\end{array}$ & Saurida undosquamis & - & - & + & - \\
\hline $\begin{array}{l}\text { Order: Cyprinodontiformes } \\
\text { Family: Hemiramphidae }\end{array}$ & Hemiramphus far & - & - & + & + \\
\hline $\begin{array}{l}\text { Order: Scorpaeniformes } \\
\text { Family: Scorpaenidae }\end{array}$ & Tetraroge barbata & - & - & + & - \\
\hline $\begin{array}{l}\text { Order: Perciformes } \\
\text { Family: Ambassidae }\end{array}$ & Ambassis interruptus & + & + & + & + \\
\hline \multirow{2}{*}{ Family: Terapontidae } & Pelates quadrilineatus & - & - & + & - \\
\hline & Terapon jarbua & + & - & + & + \\
\hline Family: Sillaginidae & Sillago sihama & - & - & + & + \\
\hline Family: Cyprinidae & Esomus sp. & + & - & - & - \\
\hline \multirow{2}{*}{ Family: Cichlidae } & Oreochromis mossambicus & + & + & + & + \\
\hline & O. niloticus & + & + & + & + \\
\hline \multirow{3}{*}{ Family: Carangidae } & Carangoides oblongus & - & - & + & - \\
\hline & Caranx ignobilis & - & - & + & - \\
\hline & C. sexfaciatus & - & - & + & - \\
\hline \multirow{3}{*}{ Family: Leiognathidae } & Leiognathus equulus & - & - & + & - \\
\hline & L. fasciatus & - & - & + & - \\
\hline & L. splendens & + & - & + & + \\
\hline \multirow{3}{*}{ Family: Lutjanidae } & Lutjanus argentimaculatus & + & + & + & + \\
\hline & L. lutjanus & - & - & + & - \\
\hline & L. russellii & - & - & + & - \\
\hline \multirow{2}{*}{ Family: Gerridae } & Gerres filamentosus & + & + & + & + \\
\hline & G. oyena & + & - & + & - \\
\hline \multirow{2}{*}{ Family: Haemulidae } & Pomadasys kaakan & - & - & + & - \\
\hline & P. maculatus & - & - & + & - \\
\hline \multirow{2}{*}{ Family: Mullidae } & Parupeneus indicus & - & - & + & - \\
\hline & Upeneus vittatus & - & - & + & - \\
\hline \multirow{2}{*}{ Family: Mugilidae } & Liza parsia & + & - & + & + \\
\hline & L. vaigiensis & + & + & + & + \\
\hline \multirow{5}{*}{ Family: Gobiidae } & Glossogobius giuris & + & + & + & + \\
\hline & Periophthalmus argentilineatus & - & - & + & - \\
\hline & Awaous ocellaris & + & + & - & - \\
\hline & Periophthalmus kalolo & - & - & + & - \\
\hline & Yongeichthys criniger & - & - & + & - \\
\hline \multirow{4}{*}{ Family: Eleotridae } & Butis butis & + & - & + & - \\
\hline & Eleotris sp. & + & - & - & - \\
\hline & Ophieleotris sp. & + & + & - & - \\
\hline & Ophiocara sp. & + & + & - & - \\
\hline
\end{tabular}


TABLE 6: Continued.

\begin{tabular}{|c|c|c|c|c|c|}
\hline Taxonomy & Species & Perennial stream & Seasonal stream & Creek & Sink \\
\hline Family: Chaetodontidae & Chaetodon decussatus & - & - & + & - \\
\hline Family: Scatophagidae & Scatophagus argus & + & - & + & + \\
\hline Family: Channidae & Channa sp. & + & - & - & - \\
\hline \multirow{2}{*}{ Family: Siganidae } & Siganus javus & - & - & + & - \\
\hline & S. vermiculatus & - & - & + & - \\
\hline \multirow{2}{*}{ Family: Acanthuridae } & Acanthurus triostegus & - & - & + & - \\
\hline & A. xanthopterus & - & - & + & - \\
\hline Family: Apogonidae & Apogon hyalosoma & + & - & + & + \\
\hline $\begin{array}{l}\text { Order: Pleuronectiformes } \\
\text { Family: Bothidae }\end{array}$ & Psettodes erumei & - & - & + & - \\
\hline Family: Soleidae & Pardachirus pavoninus & - & - & + & - \\
\hline \multirow{2}{*}{$\begin{array}{l}\text { Order: Tetraodontiformes } \\
\text { Family: Tetraodontidae }\end{array}$} & Arothron immaculatus & - & - & + & - \\
\hline & Chelonodon patoca & - & - & + & - \\
\hline
\end{tabular}

- indicates absence; + indicates presence.

TABLE 7: Diversity indices of the ichthyofaunal diversity.

\begin{tabular}{|c|c|c|c|c|}
\hline Indices & Perennial stream & Seasonal stream & Creek & Sink \\
\hline Total number of species & 21 & 11 & 48 & 14 \\
\hline Total number of individuals & 395 & 291 & 863 & 152 \\
\hline Simpson Index $\left(D_{s}\right)$ & 0.93 & 0.90 & 0.97 & 0.90 \\
\hline Shannon-Weiner Index $\left(H^{\prime}\right)$ & 2.84 & 2.34 & 3.59 & 2.45 \\
\hline Evenness $(E)$ & 0.78 & 0.94 & 0.77 & 0.83 \\
\hline Margalef's Diversity Index $(D)$ & 3.51 & 1.76 & 6.80 & 2.59 \\
\hline
\end{tabular}

O. niloticus, Lutjanus argentimaculatus, Gerres filamentosus, Liza parsia, L. vaigiensis, and Glossogobius giuris. Seven fishes were exclusively fresh water inhabitants, such as Anguilla sp., Awaous ocellaris, Channa sp., Echidna rhodochilus, Eleotris sp., Ophieleotris sp., and Ophiocara sp.

Major species found in the seasonal stream were Awaous ocellaris, Oreochromis niloticus, and Ophieleotris sp. The major inhabitants of the Perennial stream were Esomus sp., Channa sp., and Ophiocara sp. Liza vaigiensis, L. parsia, Oreochromis mossambicus, O. niloticus, Ambassis interruptus, Apogon hyalosoma, Gerres filamentosus, Lutjanus argentimaculatus, Leiognathus splendens, Scatophagus argus, Terapon jarbua, and Caranx sp. were found in both streams.

The total number of species varied among the habitats. The creek had the maximum number of species (48) and the minimum (11) was found at the seasonal stream. Overall individuals were more in creek (863) and less in sink (152). The dominance index $\left(D_{s}\right)$ in creek was the highest $(0.97)$ and lowest values (0.90) were found in seasonal stream and sink. The lowest species diversity was recorded $\left(H^{\prime}=2.34\right)$ in seasonal stream and the highest (3.59) was in creek. The evenness $(E)$ was low (0.77) in creek and high (0.94) in seasonal stream. The species richness $(D)$ was high $(6.80)$ in creek and low (1.76) in seasonal stream (Table 7).

\section{Discussion}

The fresh water fish fauna of this region is somewhat impoverished due to low habitat diversity and its long isolation from the mainland. There are possibilities that several undiscovered species living in the streams of these islands, particularly in tribal reserves and areas, are inaccessible. Vijay and Priya have observed that many endemic species of Andaman Islands and Nicobar Islands are threatened due to habitat loss and introduction of nonnative species like Oreochromis mossambicus [13]. In the present study, apart from O. mossambicus, O. niloticus was also recorded. These are hardy species adapted to a wide range of environmental conditions and have marked resistance to environmental perturbations and can disrupt the native species through competition for food and space. The fresh water moray eel Echidna rhodochilus is the new report from the Andamans as well as a first-time report from Indian waters.

Vijay and Priya collected 33 species from 77 perennial streams and 1 perennial river in Andaman Islands [13]. Among them, 17 were fresh water species. In the present study, 54 species were identified, among which 7 were exclusively fresh water. This variable percentage of fresh water species reflects a differential ecology of the habitat, which 
has more seawater influx. The species composition reflects the pattern of fish distribution across varying gradients of salinity. The perennial and seasonal streams are having many similarities and differences in their habitat ecology and faunal diversity. The similarities are in habitat and the number of riffles and pools and differences are the major and minor bends in both streams. The fresh water fauna were obviously found to be very less compared to the creek and the sink due to their confined nature. The perennial stream had continuous water flow even after the rainy season around the year. The major fish species living in this stream are Esomus sp. and Ophiocara sp. The nonperennial stream had water flow only during rainy season and most of the area dried up during the summer months. The major species in this stream are Awaous ocellaris, Oreochromis niloticus, and Ophieleotris sp.

Both the creek and the sink are brackish water habitats, characterized by a wide fluctuation in salinity due to the influence of the tide and domestic waste water influx. The presence of mangroves along the entire creek has made it highly productive. Due to these factors, the creek had high diversity of fauna with more than 40 species. The creek acts as a breeding and nursery ground for the juveniles of fish and crustaceans. It is a widely accepted fact that mangroves act as nurseries for fishes in both tropical and temperate regions [23].

The diversity indices $\left(H^{\prime}, D_{s}\right.$, and $\left.D\right)$ showed low values at the sink and the seasonal stream when compared to creek and perennial stream. The evenness index $(E)$ was very less in these areas when compared to other indices. The ichthyofaunal diversity in the perennial stream (2.84) was found to be higher than that of the seasonal stream (2.34). The seasonality can be a deterring factor for encouraging migrations of new populations and sustaining the available individuals, which prevents high diversity. However, when we consider the abundance and evenness of the available species, the seasonal stream was found to be higher (0.94). This could not be correlated with any observed feature. Also, the perennial stream had greater number of pools than the seasonal stream (Figure 2). More pools implies a higher diversity of fish communities [24]. This can be explained as a result of the habitat complexity and/or habitat volume, which is already documented for other temperate and tropical streams [25].

The diversity in the sink was high with regard to the size of the area, but it was less compared to that of the creek. Liza vaigiensis, Ambassis interruptus, Oreochromis mossambicus, L. parsia, and O. niloticus differed in their distributional patterns on all the sites, whereas other species did not differ much in their distributional patterns.

\section{Conclusions}

The present study has indicated a wide lacuna in the knowledge of fresh water species and their habitats. It is imperative to formulate conservation strategies in order to protect the native fish species and their habitats. Otherwise it is likely that several fresh water species from Andaman
Islands and Nicobar Islands may go extinct before they are even discovered by science.

\section{Conflict of Interests}

The authors declare that there is no conflict of interests regarding the publication of this paper.

\section{Acknowledgments}

The authors are grateful to Pondicherry University for providing the requisite facilities for the study. They are very thankful to all the fishermen; without their help this work would not have been achieved. The authors are indebted to Mr. A. Saravanan, Department of Disaster Management, Pondicherry University, for preparing the study area map. The corresponding author is very grateful to Mr. B. Ram Kumar, Mr. Sushant, Mr. Snehasis, Mr. Bhaskar, Mr. Chandrakant, and Mr. S. Sai Elangovan for their help.

\section{References}

[1] Committee Constituted to Holistically Address the Issue of Poaching in the Andaman and Nicobar Islands, Ministry of Environment and Forests, Government of India, New Delhi, India, 2011.

[2] T. I. Ramakrishna, C. R. Sreeraj, C. Raghunathan, R. Raghuraman, P. T. Rajan, and J. S. Yogesh Kumar, An Account of Additions to the Ichthyofauna of Andaman and Nicobar Islands, vol. 326 of Records of the Zoological Survey of India Occasional Papers, 2010.

[3] Anon, Report on the Rainfall of Port Blair, Department of Statistics and Economics. Andaman and Nicobar Administration, 2012.

[4] P. Pande, A. Kothari, and S. Singh, Directory of National Parks and Sanctuaries in Andaman and Nicobar Islands, IIPA, New Delhi, India, 1991.

[5] F. Day, "On the fishes of the Andaman Islands," in Proceedings of the Zoological Society of London, 1870, pp. 677-705.

[6] S. L. Hora, "Doryichthys insularis," in The Fresh Water Fish from the Andaman Islands, N. Annandale and S. L. Hora, Eds., vol. 27 of Records of the Indian Museum, pp. 33-41, 1925.

[7] D. D. Mukerji, "Notes on some rare and interesting fishes from the Andaman Islands, with description of two new fresh water gobies," Records of the Indian Museum, vol. 37, no. 3, pp. 250279, 1935.

[8] T. K. Sen, "Further light on fresh water fish fauna of Andaman Islands," Seafood Export Journal, vol. 7, no. 2, pp. 31-33, 1975.

[9] A. W. C. T. Herre, "On a collection of Littoral and fresh water fishes from Andaman Islands," Records of the Indian Museum, vol. 41, pp. 327-372, 1939.

[10] A. W. C. T. Herre, "A list of the fishes known from the Andaman Islands," Memoirs of Indian Museum, vol. 13, pp. 331-403, 1941.

[11] F. P. Koumans, "On the collection of gobioid fishes from Andamans," Records of the Indian Museum, vol. 42, pp. 15-18, 1940.

[12] P. K. Talwar, "Fishes of the Andaman and Nicobar Islands: a synoptic analysis," Journal of Andaman Science Association, vol. 6, no. 2, pp. 71-102, 1990. 
[13] P. Vijay and D. Priya, "A survey of fresh water fishes of the Andaman Islands," Journal of the Bombay Natural History Society, vol. 106, no. 1, pp. 264-267, 2009.

[14] R. A. Zampella, J. F. Bunnell, K. J. Laidig, and N. A. Procopio, "Using multiple indicators to evaluate the ecological integrity of a coastal plain stream system," Ecological Indicators, vol. 6, no. 4, pp. 644-663, 2006.

[15] P. L. Angermeier and I. J. Schlosser, "Species-area relationships for stream fishes," Ecology, vol. 70, no. 5, pp. 1450-1462, 1989.

[16] J. A. Baker and S. A. Foster, Estimating Density and Abundance of Endemic Fishes in Hawaiian Streams, Division of Aquatic Resources, Department of Land and Natural Resources, Honolulu, Hawaii, USA, 1992.

[17] APHA, Standard Methods, American Public Health Association, Washington, DC, USA, 19th edition, 1995.

[18] W. Fischer and G. Bianchi, Eds., FAO Species Identification Sheets for Fishery Purposes. Western Indian Ocean (Fishing Area 51), vol. 1-6, Danish International Development Agency (DANIDA), Food and Agriculture Organization of the United Nations, Rome, Italy, 1984.

[19] P. K. Talwar and A. G. Jhingran, Inland Fishes of India and Adjacent Countries (Vols 1-2), Oxford \& IBH Publishing, New Delhi, India, 1991.

[20] D. V. Rao, K. Devi, and P. T. Rajan, "An account of icthyofauna of Andaman and Nicobar Islands, Bay of Bengal," Records of ZSI, India. Occasional Paper 178, 2000.

[21] R. Froese and D. Pauly, "FishBase," World Wide Web electronic publication, 2014, http://www.fishbase.org/search.php.

[22] O. Hammer, D. A. T. Harper, and P. D. Ryan, "Past: paleontological statistics software package for education data analysis," Palaeontologia Electronica, vol. 4, no. 1, p. 9, 2001.

[23] H. M. Austin, "A survey of the ichthyofauna of the mangroves of western Puerto Rico December 1967-August 1968," Caribbean Journal of Science, vol. 11, no. 1-2, pp. 27-39, 1971.

[24] F. P. Gelwick, "Longitudinal and temporal comparisons of riffle and pool fish assemblages in a Northeastern Oklahoma Ozark stream," Copeia, vol. 1990, no. 4, pp. 1072-1082, 1990.

[25] O. T. Gorman and J. R. Karr, "Habitat structure and stream fish communities," Ecology, vol. 59, no. 3, pp. 507-515, 1978. 

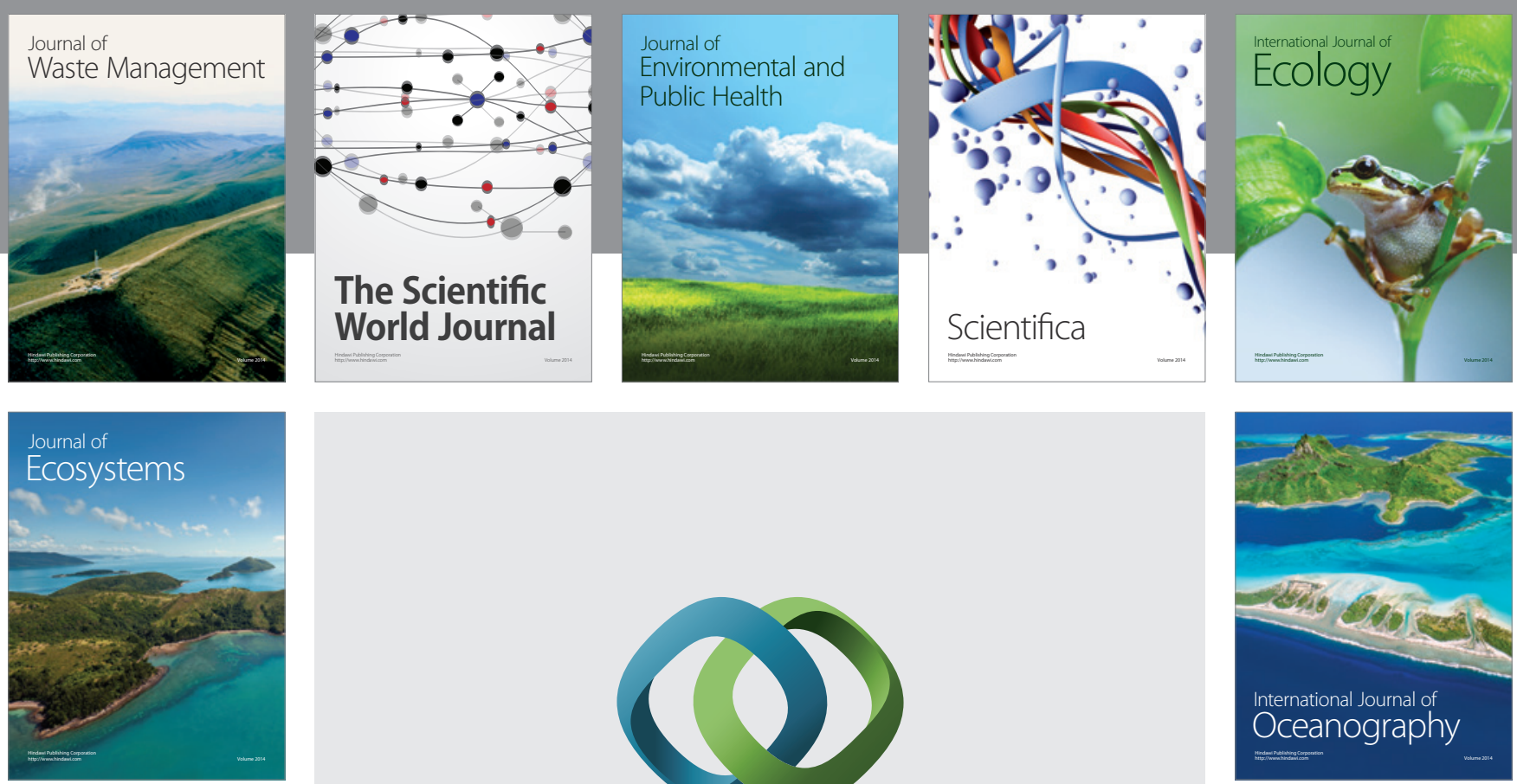

The Scientific World Journal
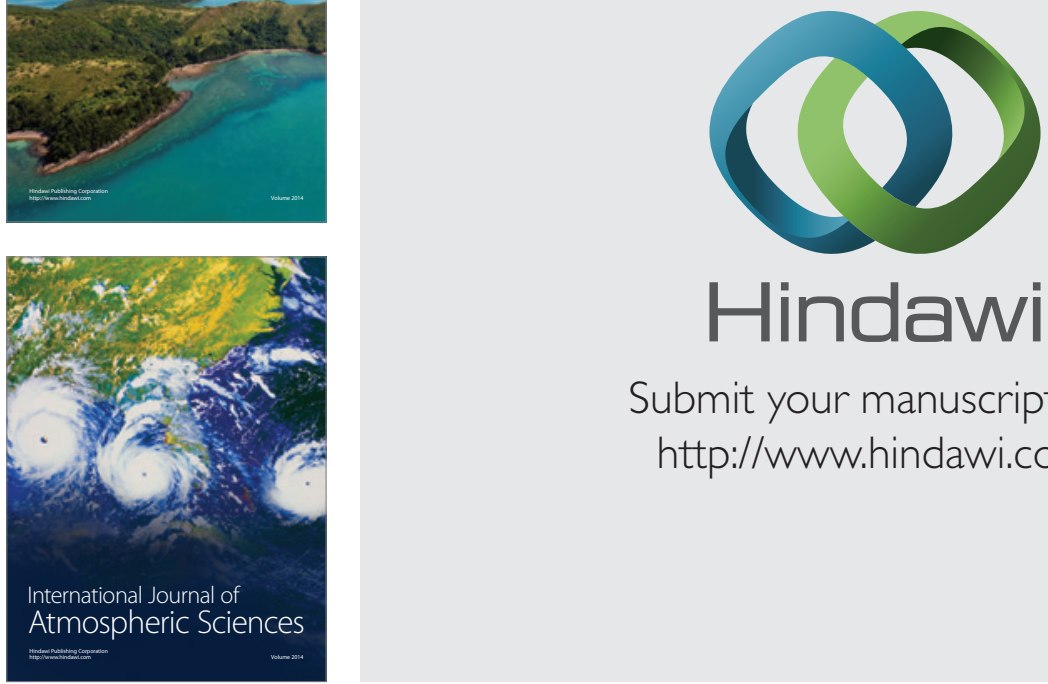

\section{Hindawi}

Submit your manuscripts at

http://www.hindawi.com
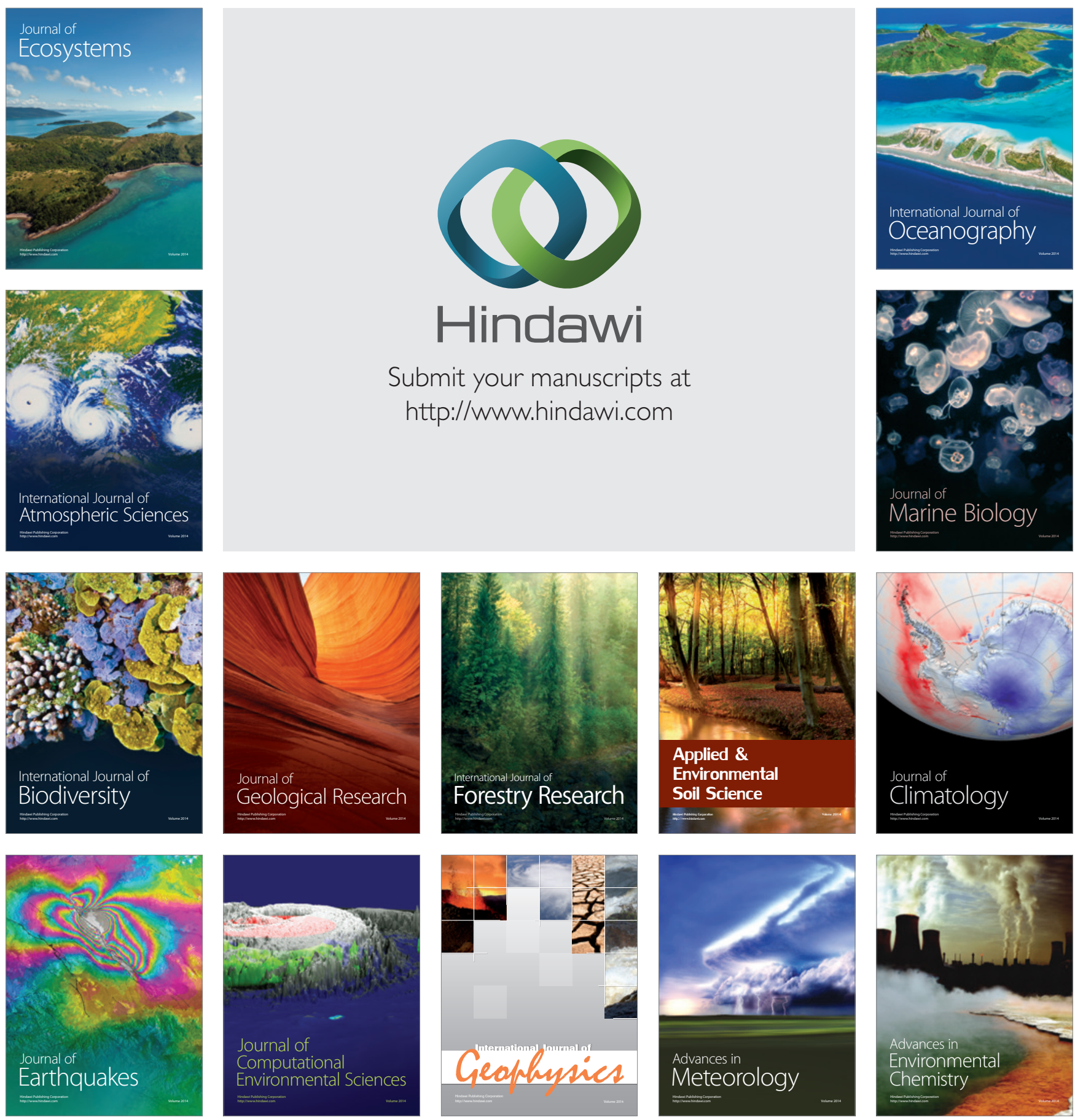